\title{
Escalated Aggression after Alcohol Drinking in Male Mice: Dorsal Raphé and Prefrontal Cortex Serotonin and 5- $\mathrm{HT}_{\mathrm{IB}}$ Receptors
}

\author{
Sara Faccidomo*,1,2, Makoto Bannai ${ }^{1,3}$ and Klaus A Miczek ${ }^{1,4}$ \\ 'Department of Psychology, Tufts University, Medford, MA, USA; 'Bowles Center for Alcohol Studies, University of North Carolina at Chapel Hill, \\ Chapel Hill, NC, USA; ${ }^{3}$ Ajinomoto Co. Inc., Institute of Life Sciences, Kawasaki, Japan; ${ }^{4}$ Departments of Psychiatry, Pharmacology and \\ Experimental Therapeutics, and Neuroscience, Tufts University, Boston, MA, USA
}

\begin{abstract}
A significant minority of individuals engages in escalated levels of aggression after consuming moderate doses of alcohol (Alc). Neural modulation of escalated aggression involves altered levels of serotonin (5-HT) and the activity of 5-HT IB receptors. The aim of these studies was to determine whether 5-HTIB receptors in the dorsal raphé (DRN), orbitofrontal (OFC), and medial prefrontal (mPFC) cortex attenuate heightened aggression and regulate extracellular levels of 5-HT. Male mice were trained to self-administer Alc by performing an operant response that was reinforced with a delivery of $6 \%$ Alc. To identify Alc-heightened aggressors, each mouse was repeatedly tested for aggression after consuming either $1.0 \mathrm{~g} / \mathrm{kg}$ Alc or $\mathrm{H}_{2} \mathrm{O}$. Next, a cannula was implanted into either the DRN, OFC, or mPFC, and subsets of mice were tested for aggression after drinking either Alc or $\mathrm{H}_{2} \mathrm{O}$ prior to a microinjection of the 5- $\mathrm{HT}$ IB agonist, CP-94,253. Additional mice were implanted with a microdialysis probe into the mPFC, through which CP-94,253 was perfused and samples were collected for 5-HT measurement. Approximately $60 \%$ of the mice were more aggressive after drinking Alc, confirming the aggression-heightening effects of $1.0 \mathrm{~g} / \mathrm{kg}$ Alc. Infusion of I $\mu$ g CP-94,253 into the DRN reduced both aggressive and motor behaviors. However, infusion of I $\mu \mathrm{g}$ CP-94,253 into the mPFC, but not the OFC, after Alc drinking, increased aggressive behavior. In the mPFC, reverse microdialysis of CP-94,253 increased extracellular levels of 5-HT; levels decreased immediately after the perfusion. This 5-HT increase was attenuated in self-administering mice. These results suggest that $5-\mathrm{HT}_{\mathrm{IB}}$ receptors in the mPFC may serve to selectively disinhibit aggressive behavior in mice with a history of Alc self-administration.

Neuropsychopharmacology (2008) 33, 2888-2899; doi:I 0.1038/npp.2008.7; published online 27 February 2008
\end{abstract}

Keywords: microinjection; microdialysis; mouse; CP-94,253; aggressive behavior; 5-HT

\section{INTRODUCTION}

Alcohol (Alc), more than any other drug, has been associated with acts of violence and aggression. Importantly, in certain situations, Alc has the ability to facilitate aggressive actions. It has been repeatedly demonstrated, in multiple species, that some individuals are sensitive to the aggression-heightening effects of moderate doses of Alc, while most are not (Chance et al, 1973; Peeke et al, 1973; Miczek and O'Donnell, 1980; Lister and Hilakivi, 1988; Miczek et al, 1993, 2004b). Although the neurobiological basis for the differential response to Alc is not yet known, there is compelling evidence for a significant role of the

* Correspondence: Dr S Faccidomo, Bowles Center for Alcohol Studies, University of North Carolina at Chapel Hill, CB \#7I78, Thurston Bowles Building, Chapel Hill, NC 27599, USA,

Tel: + 1 919-843-4389, Fax: + 1 919-966-5679,

E-mail: sara_faccidomo@med.unc.edu

Received 15 October 2007; revised 20 December 2007; accepted 7 January 2008 serotonin (5-HT) system in the modulation of impulsive aggressive behavior (Olivier et al, 1989; Olivier and Mos, 1992; Miczek et al, 2004a).

There is a long-standing 5-HT deficiency hypothesis that proposes that basal measures of both peripheral and central 5-HT activity are inversely correlated with indices of aggression and impulsivity in rodents and primates leading to the suggestion that blunted serotonergic activity might be an important factor contributing to the expression of Alcheightened aggression (Garattini et al, 1967; Giacalone et al, 1968; Coccaro, 1992; Virkkunen and Linnoila, 1993; Mehlman et al, 1994; Higley et al, 1996; van der Vegt et al, 2001). In vivo microdialysis has been used as a more sensitive tool to temporally assess this relationship. In rats, extracellular levels of 5-HT in the nucleus accumbens decrease in anticipation of an aggressive encounter while cortical 5-HT levels decrease during and after an aggressive confrontation (van Erp and Miczek, 2000; Ferrari et al, 2003). These studies reveal that 5-HT levels in specific brain regions serve to regulate distinct phases of aggressive behavior and 
perhaps the prefrontal cortex may be most involved in the execution of and recovery from an aggressive encounter (van Erp and Miczek, 2000; Halász et al, 2006; Miczek and Fish, 2006).

The influence of the $5-\mathrm{HT}_{1}$ family of receptors on aggressive behavior has been extensively studied and has revealed that $5-\mathrm{HT}_{1}$ receptor agonists can dose dependently reduce aggression alone and in the presence of Alc (Olivier and Mos, 1986; Olivier et al, 1995; Miczek et al, 1998; Fish et al, 1999; de Boer and Koolhaas, 2005; Olivier and Van Oorschot, 2005; de Almeida et al, 2006). The 5- $\mathrm{HT}_{1 \mathrm{~B}}$ receptor is of particular interest because of the behaviorally specific anti-aggressive effects of receptor-selective $5-\mathrm{HT}_{1 \mathrm{~B}}$ agonists although the effectiveness of one of the most potent $5-\mathrm{HT}_{1 \mathrm{~B}}$ agonists, $\mathrm{CP}-94,253$, depends on the type of aggressive behavior being studied and the route of administration. Specifically, systemic administration of CP-94,253 reduces several forms of escalated aggressive behavior including Alc-, instigation-, and schedule-heightened aggression (Fish et al, 1999, 2007; de Almeida et al, 2006; Bannai et al, 2007). However, the effects of local administration of CP-94,253 into the orbitofrontal cortex (OFC) are more complex and reveal that maternalinstigated aggression is insensitive to microinjection of CP-94,253 while species-typical aggression is potently reduced (de Almeida et al, 2006; Veiga et al, 2007). Together, these studies suggest that escalated and speciestypical aggression may share similar but not identical mechanisms and that the prefrontal cortex and $5-\mathrm{HT}_{1 \mathrm{~B}}$ receptors may importantly contribute to these differences.

There is a similar dissociation between anti-aggressive effects of CP-94,253 and its effects on 5-HT levels in the brain. Given systemically, CP-94,253 significantly reduces extracellular levels of 5-HT in the striatum, hippocampus, and prefrontal cortex (Knobelman et al, 2000; Johnson et al, 2001; De Groote et al, 2003; Miczek et al, 2004a). According to the 5-HT deficiency hypothesis, this decrease in 5-HT should be associated with increased aggression, not behaviorally specific anti-aggressive effects. These behavioral effects suggest that the modulation of aggression by $5-\mathrm{HT}_{1 \mathrm{~B}}$ receptors is not solely due to autoreceptor stimulation. An anatomically more discrete examination of alternate $5-\mathrm{HT}_{1 \mathrm{~B}}$ receptor populations is required to understand how this receptor regulates aggression.

The 5- $\mathrm{HT}_{1 \mathrm{~B}}$ receptor is highly expressed in brain regions related to aggressive and impulsive behavior, particularly, the prefrontal cortex (PFC) (Hoyer et al, 1985; Bruinvels et al, 1993, 1994; Sari et al, 1999; Sari, 2004). 5-HT neurons project from the dorsal raphé (DRN) to the PFC and there has been increasing evidence that dysfunctions in these neurons may underlie impulsive behavior and aggression (Grafman et al, 1996; Bechara et al, 2000; Brower and Price, 2001; Chudasama et al, 2003; Best et al, 2002; Spinella, 2004). For these reasons, presynaptic $5-\mathrm{HT}_{1 \mathrm{~B}}$ receptors located in this region might be important modulators of Alc-heightened aggression.

The objectives of these experiments were twofold. First, we asked whether $5-\mathrm{HT}_{1 \mathrm{~B}}$ receptors located in the medial prefrontal cortex (mPFC), OFC, or DRN are differentially modulating Alc-heightened aggression using site-specific microinjection of CP-94,253 prior to an aggressive confrontation. Second, we investigated the neurochemical effect of CP-94,253 in the mPFC by quantifying extracellular levels of 5-HT in both Alc-naïve and Alc self-administering mice.

\section{MATERIALS AND METHODS}

\section{Subjects}

'Residents' were 5-week-old male CFW mice (Carworth Farm Webster; Charles River Laboratories, Wilmington, MA), weighing 21-23g upon arrival, pair-housed with a female in clear, polycarbonate cages $(28 \times 17 \mathrm{~cm})$ lined with pine shavings. Purina rodent chow was freely available through the cage lid and water was given for $3 \mathrm{~h}$ daily. 'Intruders' were male CFW mice $(n=144)$ housed 8-12 per large cage $(48 \times 26 \mathrm{~cm})$ lined with corn cob bedding, with unlimited access to food and water. The vivarium maintained a 12-h light/dark photocycle (lights off at $0700 \mathrm{~h}$ ), a $21 \pm 1{ }^{\circ} \mathrm{C}$ temperature, and $23 \%$ humidity. All mice were cared for according to the Guide for the Care and Use of Laboratory Animals (National Research Council, 1996). The Tufts University IACUC approved all experiments.

\section{Alcohol Self-Administration}

A custom designed aluminum panel $(16.5 \times 15.9 \mathrm{~cm})$ was placed into the resident's home cage and secured by two thumbnail screws (Miczek and de Almeida, 2001). Each side contained a cue light positioned above a nose-poke operandum containing a drinking trough $(3 \times 5 \mathrm{~cm}$; Med Associates, Georgia, VT). Each trough was connected to a syringe pump (Med Associates). The panel and pump were interfaced with a computer controlling the experimental events and recording responses (MED-PC for Windows, v. 4.1; Med Associates). A house light at the top of the panel was illuminated throughout the session. A nose-poke was recorded when the mouse broke a photobeam spanning the operandum. Every fifth response (fixed ratio 5) was reinforced by the delivery of an Alc solution and the secondary cues of an audible click and absence of the house light. A modified sucrose-fading procedure facilitated Alc self-administration (described in Miczek and de Almeida, 2001). Drinking sessions occurred 5 days per week between 0800 and $1400 \mathrm{~h}$.

\section{Resident-Intruder Confrontations and Alcohol- Heightened Aggression}

After 3 weeks of pair-housing, the 8-week-old residents were screened for aggression until stable frequencies of attack bites were maintained (approximately 10 confrontations; Miczek and O'Donnell, 1978). Confrontations lasted for 5 min after the first attack bite or 5 min with no attack. To characterize Alc-heightened and non-heightened aggressors, aggression was assessed $15 \mathrm{~min}$ after consuming either $1.0 \mathrm{~g} / \mathrm{kg}$ Alc or water (three tests each) in an alternating sequence. On test days, aggression was tested only if the mouse drank $1.0 \mathrm{~g} / \mathrm{kg}$ Alc in less than $10 \mathrm{~min}$. Testing occurred three times per week separated by at least $48 \mathrm{~h}$. All confrontations were video-recorded and analyzed by a trained observer (intra-observer reliability: $r^{2}=0.97$ ) using The Observer software (Noldus, v.5.0; Wageningen, The Netherlands). The frequencies and durations of 
aggressive (attack bites, sideways threat, tail rattles, pursuits) and nonaggressive (grooming, rearing, walking) behaviors were quantified following the descriptions of Grant and Mackintosh (1963) and Miczek and O'Donnell (1978).

\section{Experiment 1: Intra-Raphé Microinjections and Aggression}

After characterizing Alc-heightened aggression, residents $(n=16)$ were anesthetized with Avertin ${ }^{\circledR}(2,2,2$ tribromoethanol; Sigma; $400 \mathrm{mg} / \mathrm{kg}$, i.p. ), placed into a stereotaxic frame (Kopf Instruments, Tujunga, CA), and implanted with a 26-gauge guide cannula (Plastics One, Roanoke, VA) aimed toward the DRN (AP, $-4.4 \mathrm{~mm}$; ML, \pm 0 ; DV,$-1.7 \mathrm{~mm}$ from dura; interaural, $-0.6 \mathrm{~mm}$, after Paxinos and Franklin (2001)). A 33-gauge obdurator (Plastics One), extending $0.5 \mathrm{~mm}$ beyond the cannula tip, was inserted after surgery and moved daily to prevent blockage and scarring. An aversive-tasting polish (Bite $\mathrm{It}^{\odot}$ ) coated the headmount and obdurator to prevent gnawing damage by the female cagemate. After 1- to 2-week recovery, residents resumed Alc self-administration and aggression testing.

On test days, mice consumed water or $1.0 \mathrm{~g} / \mathrm{kg}$ Alc immediately before microinjection of artificial cerebrospinal fluid (aCSF), $1.0 \mu \mathrm{g}(+) 8-\mathrm{OH}-\mathrm{DPAT}\left(5-\mathrm{HT}_{1 \mathrm{~A}}\right.$ agonist), or $1.0 \mu \mathrm{g}$ CP-94,253 (5- $\mathrm{HT}_{1 \mathrm{~B}}$ agonist). The obdurator was removed and a 33-gauge injector was (Plastics One) inserted to extend $2 \mathrm{~mm}$ beneath the guide. Flared polyethylene tubing connected the injector to a glass syringe and pump (CMA Microdialysis, North Chelmsford, MA) that infused $0.5 \mu \mathrm{l}$ over $4 \mathrm{~min}(0.125 \mu \mathrm{l} / \mathrm{min})$. The injector remained in place for $1 \mathrm{~min}$ after the infusion to allow diffusion and minimize vertical capillary action along the injection tract. Mice were unrestrained during the infusion. Aggression was tested $10 \mathrm{~min}$ after the microinjection. A total of six tests were conducted in a randomized sequence and separated by at least 4 days.

After the final aggression test, mice were deeply anesthesized $\left(\right.$ Avertin ${ }^{\circledR}$ ) and intracardially perfused with $0.9 \%$ saline and $4 \%$ paraformaldehyde. To verify implant position, the brains were sliced on a sliding microtome in $60 \mu \mathrm{m}$ coronal sections, and stained with cresyl violet (Figure 1a and b). Mice with inaccurate placements or clogged cannulae $(n=5)$ were anatomical controls and excluded from the final analysis.

\section{Experiment 2: Medial Prefrontal Cortex Microinjections and Aggression}

A second group of residents $(n=18)$ was implanted with a cannula (Plastics One) aimed at either the right or the left medial prefrontal cortex (mPFC: AP, $+1.7 \mathrm{~mm}$; $\mathrm{ML}$, $\pm 0.4 \mathrm{~mm}$; DV,$-1.2 \mathrm{~mm}$ from dura; Figure $1 \mathrm{c}$ and d). They were tested for aggression $10 \mathrm{~min}$ after consuming water or $1.0 \mathrm{~g} / \mathrm{kg} \mathrm{Alc}$ and a microinjection of either $0.5 \mu \mathrm{g}$ aCSF or $1 \mu \mathrm{g}$ CP-94,253. Histological verification of cannula placement revealed that six missed placements were within the lateral septum; these were analyzed independently (data not shown). Two mice had clogged cannula and were excluded from the study.

\section{Experiment 3: Orbitofrontal Cortex Microinjections and Aggression}

A third group of residents $(n=18)$ was implanted with a cannula (Plastics One) aimed at either the right or the left orbitofrontal cortex (OFC: AP, $+2.5 \mathrm{~mm}$; ML, $\pm 0.7 \mathrm{~mm}$; $\mathrm{DV},-1.0 \mathrm{~mm}$ from dura). Mice were tested for aggression $10 \mathrm{~min}$ after consuming water or $1.0 \mathrm{~g} / \mathrm{kg} \mathrm{Alc}$, and a microinjection of either $0.5 \mu \mathrm{g}$ aCSF or $1 \mu \mathrm{g}$ CP-94,253. The final analysis included 13 residents with accurate OFC injections; three mice died after surgery and two had cannulae placements outside the OFC (Figure 1e and f).

\section{Experiment 4: Measurement of Extracellular 5-HT in the Medial Prefrontal Cortex}

A group of experimentally naïve mice $(n=5)$ and a group of mice $(n=5)$ that drank $1.0 \mathrm{~g} / \mathrm{kg}$ Alc daily (see Alc selfadministration for details) were implanted with a CMA/7 guide cannula (CMA Microdialysis) aimed $2 \mathrm{~mm}$ above the mPFC (AP, + $1.7 \mathrm{~mm}$; ML, $+0.3 \mathrm{~mm}$ from bregma; DV, $-1.5 \mathrm{~mm}$ from skull surface) and given at least 1 week to recover.

On the evening before sample collection, mice were anesthesized using isoflurane inhalation anesthesia (AErrane ${ }^{\mathbb{R}}$; Baxter, IL) and a CMA/7 microdialysis probe (membrane length, $2 \mathrm{~mm}$ ) was inserted into the guide cannula. Fluorinated ethylene polymer tubing (CMA Microdialysis) connected the probe to the single-channel swivel (Instech, Plymouth Meeting, PA), liquid switch (CMA/1100), and syringe pump (CMA/102). The swivel arm allowed free $360^{\circ}$ movement of the tethered mouse in its home cage. The probe was perfused with aCSF at a rate of $0.4 \mu \mathrm{l} / \mathrm{min}$ overnight and increased to $0.8 \mu \mathrm{l} / \mathrm{min} 1 \mathrm{~h}$ before sample collection. Samples were collected every $20 \mathrm{~min}$, and stored at $-80^{\circ} \mathrm{C}$ for future analysis. Three 1 -h collection periods (total of nine samples) occurred for baseline, the addition of CP-94,253 $(1 \mu \mathrm{M})$ to the perfusate and the removal of CP-94,253 from the perfusate. The mice were anesthetized with Avertin ${ }^{\circledR}$ and intracardially perfused to verify probe placement (Supplementary Figure 1).

Serotonin was analyzed by high-performance liquid chromatography (HPLC). Ten-microliter samples were injected onto an Inersil ODS-3 microbore column $(3 \mu \mathrm{m}$, $1 \times 150 \mathrm{~mm}$; LC PACKINGS, Amsterdam, Netherlands) connected to a manual injector (model 7725i; Rheodyne, Cotati, CA) with a $20 \mu \mathrm{l}$ sample loop and an LC-10ADVP pump (Shimadzu, Kyoto, Japan). An electrochemical detector (VT-03 micro flow cell; ANTEC Leyden, Zoeterwoude, Netherlands) was set at a potential of $600 \mathrm{mV}$ against an $\mathrm{Ag} / \mathrm{AgCl}$ reference electrode. The signals were detected and analyzed using Control and ChromoGraph Report software (Bioanalytical Systems, West Lafayette, IN), respectively. The mobile phase $\left(25 \mathrm{mM} \mathrm{NaH} \mathrm{PO}_{4}, 50 \mathrm{mM}\right.$ sodium citrate, $27 \mu \mathrm{M} \mathrm{Na}{ }_{2}$ EDTA, and $2.2 \mathrm{mM}$ 1-octanosulfonic acid, $8 \% \mathrm{MeOH}, \mathrm{pH} 4.2$ ) was pumped at a flow rate of $80 \mu \mathrm{l} / \mathrm{min}$. A standard curve for 5-HT (Fluka; SigmaAldrich, St Louis, MO) was generated every day and mouse samples were stored at $-80^{\circ} \mathrm{C}$ and analyzed within $24 \mathrm{~h}$. Peak heights for 5-HT quantified the concentration within each sample. 
a
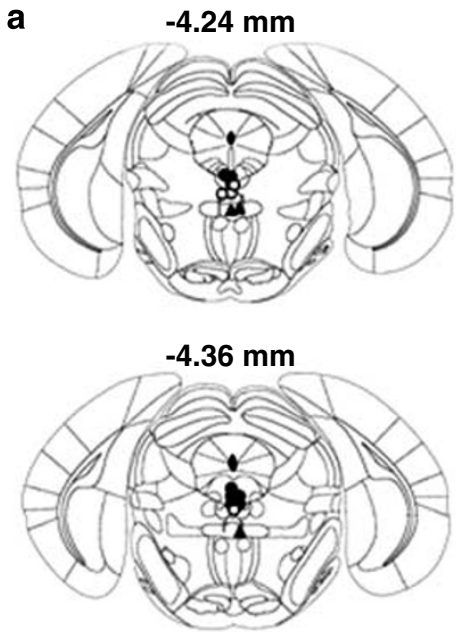

C

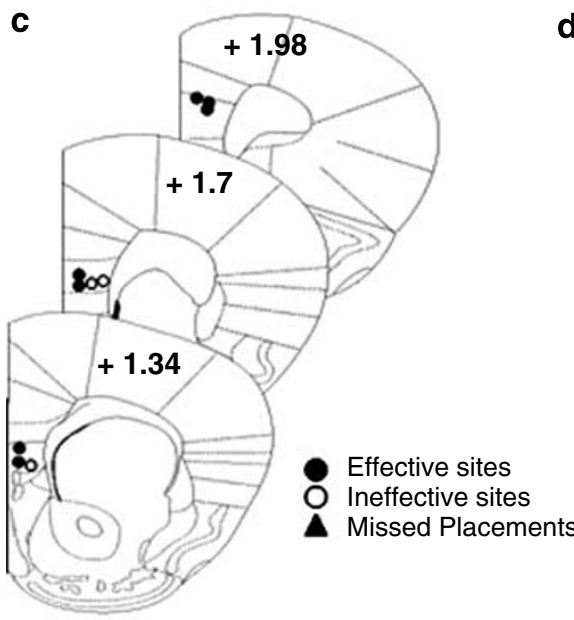

e

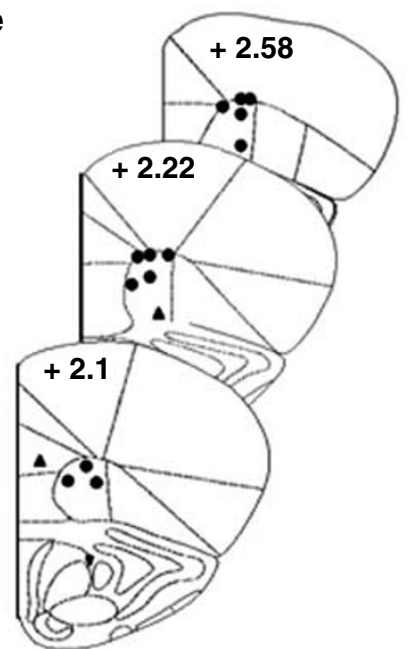

b

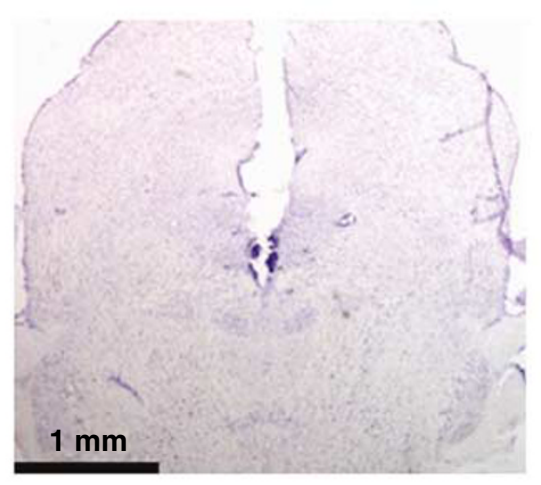

d

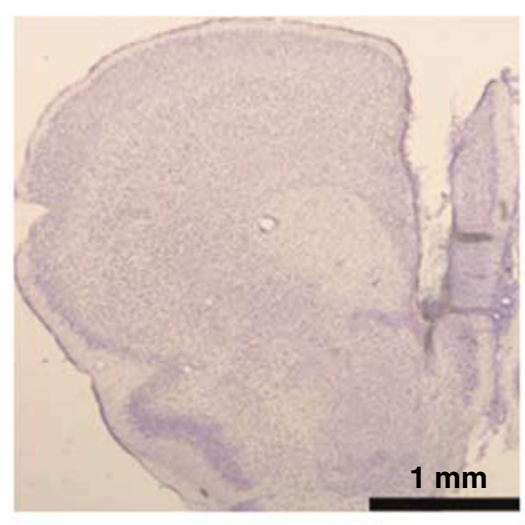

f

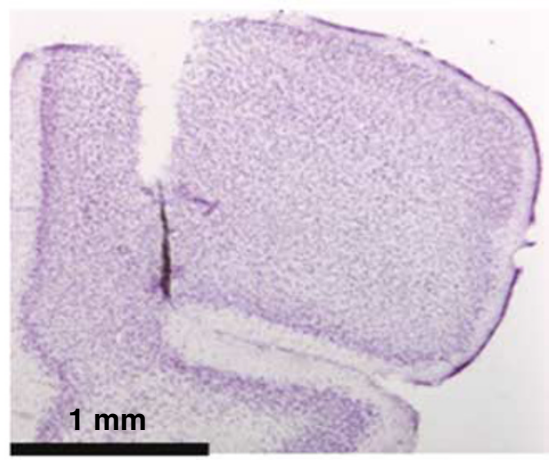

Figure I Distribution of microinjection sites. (a, c, e) A schematic representation of mouse dorsal raphé (DRN), medial prefrontal (mPFC), and orbitofrontal (OFC) cortex coronal sections adapted from Paxinos and Franklin. Circles indicate the approximate site of an accurately placed injection aimed at AP, $-4.4 \mathrm{~mm}$; $\mathrm{ML}, \pm 0 \mathrm{~mm}$; DV, $-1.7 \mathrm{~mm} ; \mathrm{AP},+1.7 \mathrm{~mm} ; \mathrm{ML}, \pm 0.4 \mathrm{~mm}$; DV, $-1.2 \mathrm{~mm}$; and $\mathrm{AP},+2.5 \mathrm{~mm} ; \mathrm{ML}, \pm 0.7 \mathrm{~mm}$; DV, $-1.0 \mathrm{~mm}$, respectively. Triangles represent missed placements. Filled circles represent anatomical sites into which a I $\mu$ g infusion of CP-94,253 effectively reduced (>40\% decrease) species-typical aggression (a) and effectively increased (>40\% increase) Alc-heightened aggression (c). (b, d, f) Representative mouse brain coronal sections $(\times 20)$ that were stained with cresyl violet to visualize the injection sites in the DRN, mPFC, and OFC, respectively. The black horizontal bar represents I mm.

\section{Drugs}

Ethyl alcohol (95\%) (Pharmco Products Inc., Brookfield, CT) was diluted with tap water to $10 \%(\mathrm{w} / \mathrm{v})$. The $5-\mathrm{HT}_{1 \mathrm{~A}}$ agonist, (+ )8-OH-DPAT (8-hydroxy-[dipropyl- $n$-amine] tetralin; Research Biochemicals International, Natick, MA) and the 5- $\mathrm{HT}_{1 \mathrm{~B}}$ agonist, CP-94,253 (3-[1,2,5,6-tetrahydro-4pyridyl]-5-propoxypirolo[3,2-b]pyridine, generously donated 
by Pfizer, Groton, CT) were freshly dissolved in aCSF (in $\mathrm{mM}, 147 \mathrm{NaCl}, 1.3$ anhydrous $\mathrm{CaCl}_{2}, 0.9$ anhydrous $\left.\mathrm{MgCl}_{2}, 4.0 \mathrm{KCl}, \mathrm{pH}=6.7-7\right)$.

\section{Statistical Analysis}

The frequencies of the aggressive behaviors and the durations of the non-aggressive behaviors were analyzed using two-way repeated-measures ANOVA. The HolmSidak post-hoc test was run when appropriate, using the aCSF and water tests as the control conditions.

After verifying no systematic trends, baseline levels of 5-HT were quantified by averaging the three baseline samples for each individual mouse. 5-HT levels for the subsequent six samples were expressed as a percent of baseline for each subject. For analysis, a two-way between-subject ANOVA was performed followed by the Holm-Sidak post-hoc test, using the average baseline level of 5-HT and naive mice as the common controls. $\alpha$ was set at 0.05 for all analyses.

\section{RESULTS}

The most striking finding from these experiments is the very high level of aggression observed after drug microinjection. In all the experiments, aggressive behavior was significantly increased after microinjection of aCSF and selfadministration of $1.0 \mathrm{~g} / \mathrm{kg} \mathrm{Alc}$, even in those subjects who were previously characterized as 'alcohol non-heightened aggressors' prior to surgery. Because of their similar behavioral response to Alc during the microinjection phase of the experiments, Alc-heightened and non-heightened aggressors were analyzed as a single experimental group.

\section{Experiment 1: Intra-Raphé Microinjections and Aggression}

Intra-raphe administration of the prototypic $5-\mathrm{HT}_{1 \mathrm{~A}}$ agonist, 8-OH-DPAT, decreases both species-typical and maternal aggression in rats (Mos et al, 1993; de Almeida and Lucion, 1997). This finding was extended to Alc self-administering mice and to a $5-\mathrm{HT}_{1 \mathrm{~B}}$ receptor agonist. Accordingly, there was a significant main effect of fluid consumption on the frequency of attack bites $\quad\left(\mathrm{F}_{(1,20)}=21.05, \quad p<0.001\right)$ and sideways threats $\left(F_{(1,20)}=16.95, p=0.002\right)$. Post-hoc tests revealed that this effect was specifically due to heightened levels of aggressive behavior after self-administration of $1.0 \mathrm{~g} / \mathrm{kg}$ Alc, regardless of the drug that was microinjected (Figure 2a; Table 1). In addition, a significant main effect of drug was found on the frequency of attack bites $\left(\mathrm{F}_{(2,20)}=9.45, p=0.001\right)$ and sideways threats $\left(\mathrm{F}_{(2,20)}=9.4, p=0.001\right)$. Both $1 \mu \mathrm{g}(+) 8$ OH-DPAT and $1 \mu \mathrm{g}$ CP-94,253 significantly decreased the frequency of attack bites while the frequency of sideways threat was only affected by infusion of $1 \mu \mathrm{g}$ CP-94,253. Finally, microinjection of $1 \mu \mathrm{g}(+) 8-\mathrm{OH}-\mathrm{DPAT}$ effectively reduced the frequency of tail rattles $\left(\mathrm{F}_{(2,20)=9.46 \text {, }}\right.$ $p=0.001)$. Microinjection sites that effectively reduced the frequency of attack bites after water drinking and 1- $\mu \mathrm{g} \mathrm{CP-}$ 94,253 infusion compared to water drinking and aCSF infusion by at least $40 \%$ are indicated in Figure 1a with closed circles.
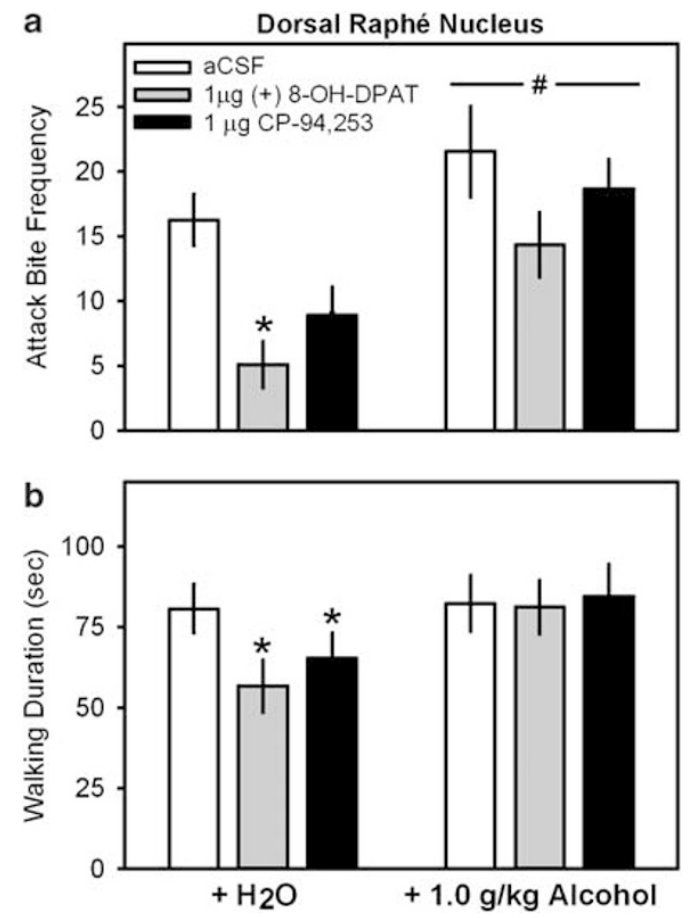

Figure 2 Microinjection of $5-\mathrm{HT}$, agonists into the dorsal raphé after water or Alc consumption. (a) The effect of the aCSF vehicle (open bars), 8-OH-DPAT (filled gray bars), or CP-94,253 (filled black bars) on the mean ( \pm SEM, vertical lines) frequency of attack bites after the consumption of water $\left(+\mathrm{H}_{2} \mathrm{O}\right.$, left side) or $1.0 \mathrm{~g} / \mathrm{kg}$ Alc $(+1.0$ Alc, right side). (b) The effects of these drugs on the duration of walking (in seconds). *A significant decrease from the aCSF vehicle; ${ }^{*}$ a significant main effect of Alc selfadministration. $p<0.05$ for all comparisons.

A significant main effect on the duration of walking was observed $\left(\mathrm{F}_{(1,20)}=5.69, p=0.038\right)$. Post-hoc analysis revealed that, overall, mice were more active after selfadministration of $1.0 \mathrm{~g} / \mathrm{kg}$ Alc relative to water (Figure $2 \mathrm{~b}$; Table 1). The main effect of drug was obtained for the duration of grooming $\left(\mathrm{F}_{(2,20)}=4.52, p=0.024\right)$. Specifically, microinjection of $1 \mu \mathrm{g}$ CP-94,253 reduced the duration of grooming by $32 \%$.

\section{Experiment 2: Medial Prefrontal Cortex Microinjections and Aggression}

As in the first experiment, levels of aggression were significantly elevated after self-administration of $1.0 \mathrm{~g} / \mathrm{kg}$ Alc regardless of drug treatment $\left(\mathrm{F}_{(1,18)}=7.55, p=0.023\right.$; Figure $3 \mathrm{a}$ ). In addition, there was a significant interaction between self-administered fluid and drug dose, and post-hoc tests revealed that after Alc self-administration, microinjection of $1.0 \mu \mathrm{g}$ CP-94,253 significantly increased the frequency of attack bites during the 5-min confrontation as compared to the level after aCSF microinjection $(p=0.004$; Figure $3 a)$. Microinjection sites that effectively increased the frequency of attack bites after ethanol drinking and $1 \mu \mathrm{g}$ CP-94,253 infusion compared to ethanol drinking and aCSF infusion by at least $40 \%$ are indicated in Figure 1c with closed circles.

A significant main effect of drug dose $\left(\mathrm{F}_{(2,18)}=5.03\right.$, $p=0.018$; Figure $3 \mathrm{c}$ ) as well as a significant interaction 
Table I Effects of Intra-Raphé Microinjection of (+)8-OH-DPAT and CP-94,253 on Aggressive and Non-aggressive Behaviors after SelfAdministration of Alcohol or Water

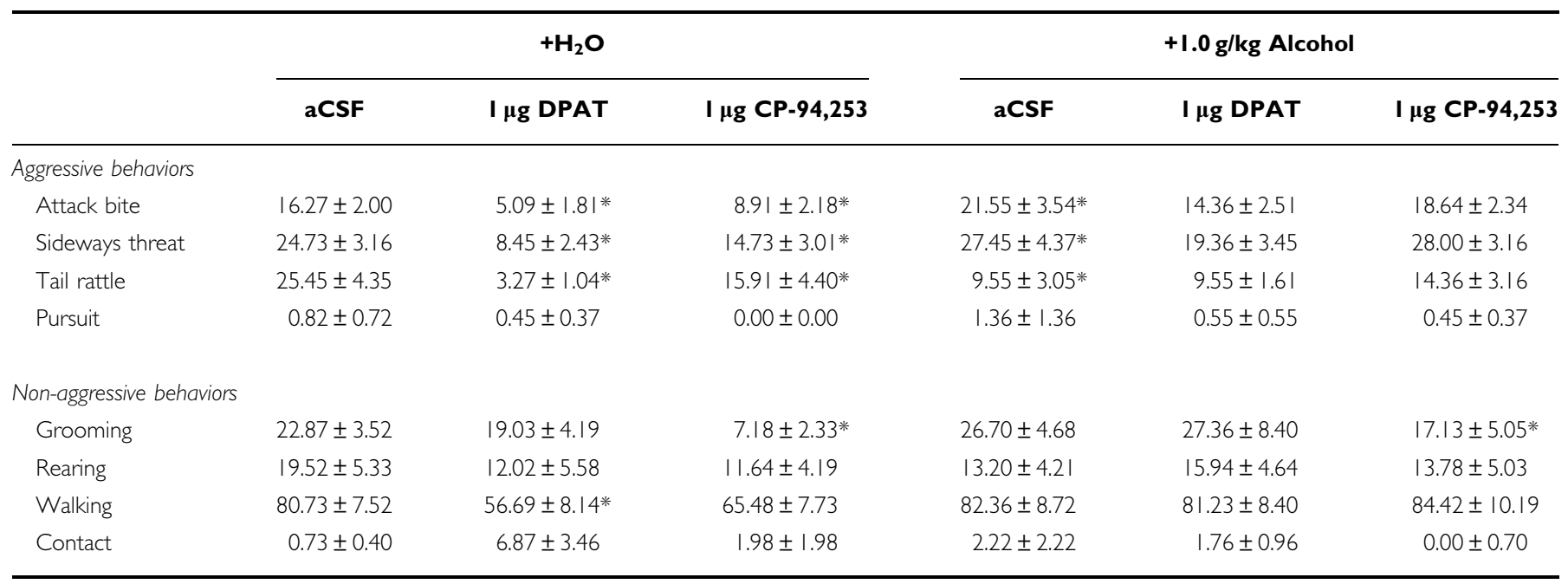

Frequencies of aggressive behaviors and durations of non-aggressive behaviors are represented as mean \pm SEM.

*Statistical significance from control, $p<0.05$.
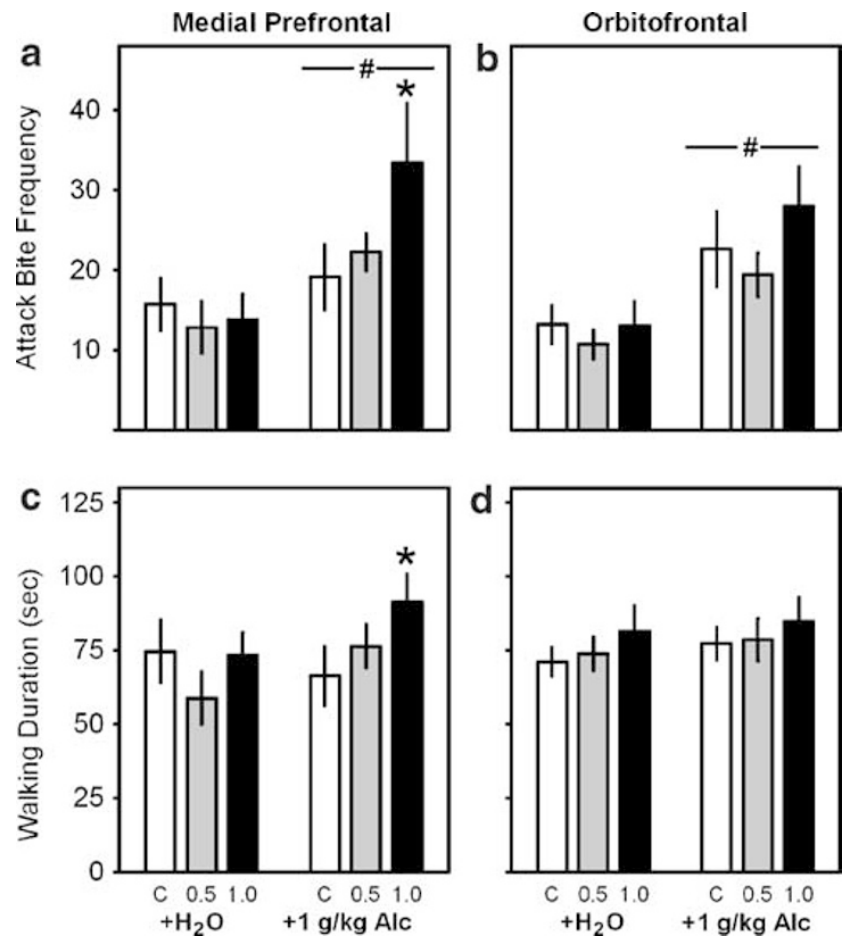

Figure 3 Microinjection of the $5-\mathrm{HT}_{\text {IB }}$ receptor agonist CP-94,253 into the prefrontal cortex after water or Alc consumption. (a) The effects of medial prefrontal microinjection and (b) the effects of orbitofrontal microinjection of the aCSF vehicle (open bars) and the 5-HT IB agonist CP94,253 at the 0.5 (filled gray bars) and I.0 $\mu$ g doses (filled black bars) on the mean ( \pm SEM, vertical lines) frequency of attack bites after the consumption of water $\left(+\mathrm{H}_{2} \mathrm{O}\right.$, left side) or $1.0 \mathrm{~g} / \mathrm{kg} \mathrm{Alc}(+1.0 \mathrm{Alc}$, right side). (c and $\mathbf{d}$ ) The effects of these treatments on the duration of walking (in seconds) in these two regions, respectively. *A significant decrease from the aCSF vehicle; ${ }^{*}$ a significant main effect of Alc self-administration. $p<0.05$ for all comparisons.

$\left(F_{(2,18)}=3.29, p=0.018\right)$ was found for the duration of walking. These results indicate that, while microinjection of $1 \mu \mathrm{g}$ CP-94,253 alone is not sufficient to modulate motor activity, when paired with self-administration of $1.0 \mathrm{~g} / \mathrm{kg}$ Alc, the effects on motor activity are additive and result in locomotor hyperactivity. Similarly, a significant main effect of self-administered fluid $\left(\mathrm{F}_{(1,18)}=5.5, p=0.044\right)$ and an interaction $\left(\mathrm{F}_{(2,18)}=3.92, p=0.039\right)$ were found for grooming duration. Post-hoc analysis revealed that this interaction was due to a significant decrease in the duration of grooming after consuming water and microinjection with $0.5 \mu$ g CP-94,253 (Table 2).

Analysis of the mice with placements in the lateral septum revealed a higher frequency of attack bites $\left(\mathrm{F}_{(1,4)}=28.05\right.$,

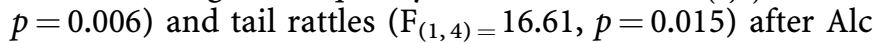
drinking compared to water self-administration (Figure 4) without a significant interaction between self-administered fluid and drug dose. In addition, walking duration was significantly increased after Alc self-administration irrespective of drug dose $\left(\mathrm{F}_{(1,4)}=13.59, p=0.021\right.$; Figure 4).

\section{Experiment 3: Orbitofrontal Cortex Microinjections and Aggression}

As in the previous two experiments, there was a significant main effect of self-administered fluid on the frequency of attack bites $\left(\mathrm{F}_{(1,24)}=14.91, p=0.002\right)$ and sideways threats $\left(\mathrm{F}_{(1,24)}=15.31, p=0.002\right.$; Figure $3 \mathrm{~b}$, Table 3). Post-hoc analysis revealed that these measures of aggressive behavior were significantly increased after Alc relative to water selfadministration, independent of drug microinjection.

The only significant main effect of drug was found for rearing duration $\left(\mathrm{F}_{(2,24)}=4.79, p=0.018\right.$; Table 3). Post-hoc analysis revealed that $1.0 \mu \mathrm{g}$ CP-94,253 significantly increased the duration of rearing relative to aCSF microinjection.

\section{Experiment 4: Measurement of Extracellular 5-HT in the Medial Prefrontal Cortex}

There were significant main effects of drinking history $\left(\mathrm{F}_{(1,56)}=22.80, p<0.001\right)$, time $\left(\mathrm{F}_{(6,56)}=11.24, p<0.001\right)$, 
Table 2 Effects of Microinjection of CP-94,253 into the Infralimbic Cortex on Aggressive and Non-aggressive Behaviors after selfAdministration of Alcohol or Water

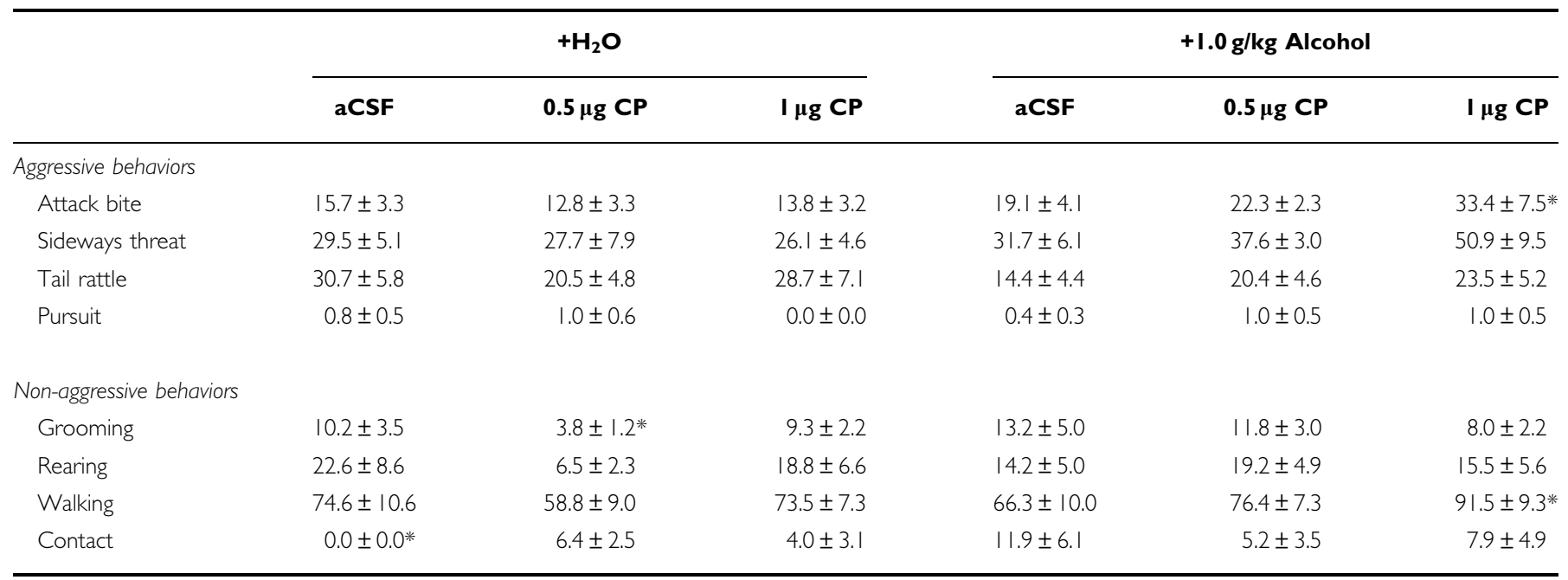

Frequencies of aggressive behaviors and durations of non-aggressive behaviors are represented as mean $\pm \mathrm{SEM}$.

*Statistical significance from control, $p<0.05$.
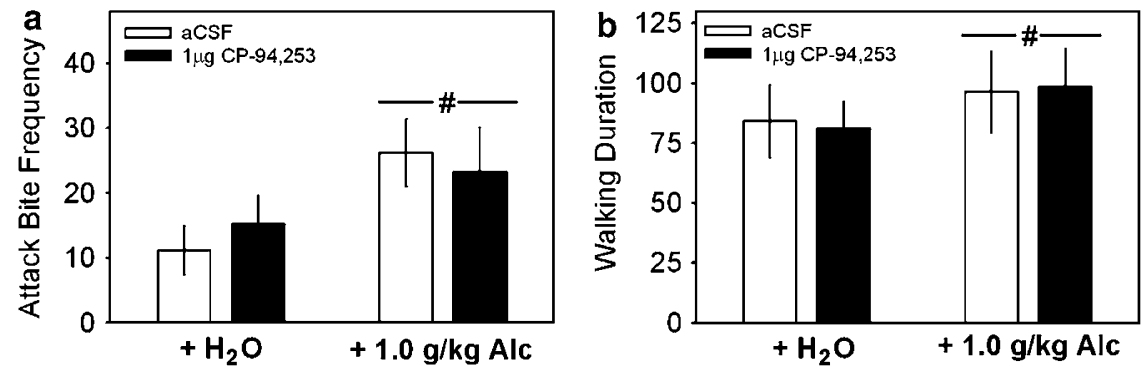

Figure 4 Microinjection of the 5-HT IB receptor agonist CP-94,253 into the lateral septum after water or Alc consumption. (a) The effect of the aCSF vehicle (open bars) and $1.0 \mu \mathrm{g}$ CP-94,253 (filled black bars) on the mean ( \pm SEM, vertical lines) frequency of attack bites after the consumption of water $\left(+\mathrm{H}_{2} \mathrm{O}\right.$, left side) or $1.0 \mathrm{~g} / \mathrm{kg}$ Alc ( + I.0 Alc, right side). (b) The effects of these treatments on the duration of walking (in seconds). ${ }^{\#} \mathrm{~A}$ significant main effect of Alc self-administration. $p<0.05$ for all comparisons.

and a significant interaction between both factors $\left(\mathrm{F}_{(6,56)}=2.80, p=0.019\right)$ on the levels of extracellular 5HT in the mPFC (Figure 5). 5-HT levels in both groups of mice were significantly lower 160-200 min after the start of the session, during recovery from the reverse perfusion of CP-94,253. In addition, mice with a history of Alc selfadministration showed a blunted neurochemical response to CP-94,253 during the reverse perfusion.

\section{DISCUSSION}

This series of experiments demonstrates that the expression of Alc-heightened aggression is functionally regulated specifically by $5-\mathrm{HT}_{1 \mathrm{~B}}$ receptor activity in the $\mathrm{mPFC}$ but not in the OFC or the DRN. Furthermore, the potentiation of Alc-heightened aggression that is observed after local infusion of CP-94,253 into the MPFC may be due to blunted cortical levels of 5-HT in Alc self-administering mice. This pattern of results contrasts with the critical role of the orbito ventral region of the prefrontal cortex in other forms of escalated aggression and suggests that the mechanism underlying Alc-heightened aggression may differ from that of other types of escalated aggressive behavior (de Almeida et al, 2006; Bannai et al, 2007).

These are the first studies that provide evidence toward the respective roles of pre- and post-synaptic $5-\mathrm{HT}_{1 \mathrm{~B}}$ receptors in modulating Alc-heightened and species-typical aggression. The attenuation of species-typical aggression by intra-raphé microinjection of $(+) 8-\mathrm{OH}-\mathrm{DPAT}$ (experiment 1) corroborates the earlier findings of Mos et al (1993) and de Almeida and Lucion (1997) and highlights the importance of somatodendritic $5-\mathrm{HT}_{1}$ receptors in the modulation of species-typical aggression. This experiment extends this research by showing that local activation of DRN $5-\mathrm{HT}_{1 \mathrm{~B}}$ receptors produces a similar behavioral effect to $5-\mathrm{HT}_{1 \mathrm{~A}}$ receptor activation (ie, attenuation of aggression), coupled with modest reductions in motor behavior. The slight slowing of motor activity seen after CP-94,253 injection was somewhat surprising, given the absence of this effect on species-typical aggression when the drug is systemically administered, but not entirely unexpected because the effect of CP-94,253 on motor activity is dependent on the experimental conditions in which it is administered (Fish et al, 1999, 2007). Nonetheless, the results from experiment 1 suggest that activation of $\mathrm{DRN} 5-\mathrm{HT}_{1 \mathrm{~B}}$ receptors leads to a 
Table 3 Effects of Microinjection of CP-94,253 into the Orbitofrontal Cortex on Aggressive and Non-aggressive Behaviors after SelfAdministration of Alcohol or Water

\begin{tabular}{|c|c|c|c|c|c|c|}
\hline & \multicolumn{3}{|c|}{$\mathrm{H}_{2} \mathbf{O}$} & \multicolumn{3}{|c|}{$+1.0 \mathrm{~g} / \mathrm{kg}$ Alcohol } \\
\hline & aCSF & $0.5 \mu \mathrm{g} C P$ & $\mathrm{I} \mu \mathrm{g} \mathbf{C P}$ & aCSF & $0.5 \mu \mathrm{g} C P$ & I $\mu \mathrm{g}$ CP \\
\hline Attack bite & $13.2 \pm 2.4$ & $|0.7 \pm| .8 \mid$ & $13.0 \pm 3.0$ & $22.6 \pm 4.7 *$ & $19.4 \pm 2.7^{*}$ & $27.9 \pm 5.0 *$ \\
\hline Sideways threat & $19.6 \pm 3.8$ & $17.7 \pm 3.0$ & $20.4 \pm 4.9$ & $31.5 \pm 5.1 *$ & $27.4 \pm 3.6 *$ & $38.2 \pm 7.0 *$ \\
\hline \multicolumn{7}{|l|}{ Non-aggressive } \\
\hline Grooming & $15.8 \pm 3.7$ & $\mid 1.1 \pm 3.5$ & $8.9 \pm 2.3$ & $11.8 \pm 3.0$ & $21.9 \pm 11.5$ & $11.8 \pm 2.9$ \\
\hline Rearing & $36.8 \pm 7.2$ & $34.3 \pm 4.6$ & $36.7 \pm 6.7 *$ & $27.6 \pm 6.4$ & $18.3 \pm 5.3$ & $38.6 \pm 7.2 *$ \\
\hline Walking & $71.1 \pm 4.9$ & $74.0 \pm 5.7$ & $81.6 \pm 8.6$ & $77.4 \pm 5.6$ & $78.7 \pm 7.1$ & $84.9 \pm 8.0$ \\
\hline
\end{tabular}

Frequencies of aggressive behaviors and durations of non-aggressive behaviors are represented as mean $\pm \mathrm{SEM}$.

*Statistical significance from control, $p<0.05$.

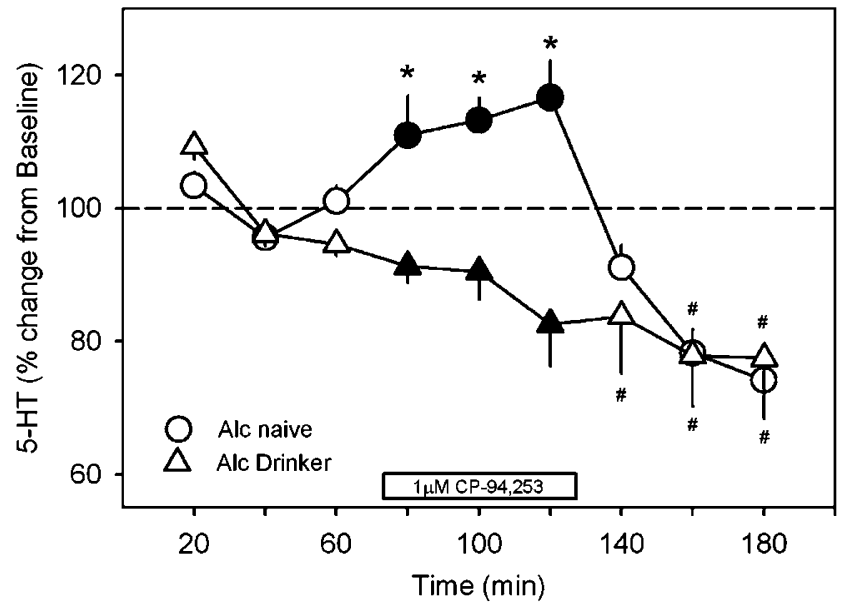

Figure 5 Cortical levels of 5-HT measured during reverse perfusion of $5-\mathrm{HT}_{\text {IB }}$ receptor agonist CP-94,253. Circles reflect the mean ( \pm SEM, vertical lines) change in extracellular level of 5-HT in a 20-min sample in Alc-naïve mice and triangles reflect the mean ( \pm SEM, vertical lines) change in extracellular level of 5-HT in a 20-min sample in chronic AlcAlc drinkers. All data are expressed as a percent change from baseline. Filled symbols reflect samples that were collected during the reverse perfusion of I $\mu \mathrm{M}$ CP-94,253. The dashed line denotes 100\%. *A significant difference between treatment groups at that time point; ${ }^{*}$ a significant change from baseline. $p<0.05$ for all comparisons.

nonspecific reduction in non-heightened aggressive behavior. This conclusion is concordant with a recent study showing that intra-raphé microinjection of the $5-\mathrm{HT}_{1 \mathrm{~B}}$ agonist, CP-93,129, nonspecifically decreases scheduleheightened levels of aggression (Bannai et al, 2007). Since $5-\mathrm{HT}_{1}$ agonists infused directly into the DRN produce a generalized decrease in 5-HT release in all terminal regions of the brain, the function of decreased extracellular 5-HT could be to inhibit motor activity via decreased 5-HT availability in terminal regions that are dopamine-rich and important for regulating motor activity, such as the dorsal striatum (Adell et al, 1993; Adell et al, 2001). Thus, the behavioral specificity of CP-94,253 that occurs after systemic administration, in contrast to the $5-\mathrm{HT}_{1 \mathrm{~A}}$ agonist $(+) 8-\mathrm{OH}-\mathrm{DPAT}$, could be due to joint stimulation of somatodendritic and post-synaptic $5-\mathrm{HT}_{1 \mathrm{~B}}$ receptors by $\mathrm{CP}-$ $94,253 v s$ stimulation of primarily somatodendritic receptors by low doses of $(+) 8-\mathrm{OH}-\mathrm{DPAT}$.

It is significant that the expression of Alc-heightened aggression was insensitive to intra-raphé infusion of either of these agonists in light of the recent report by Bannai et al (2007) showing a significant reduction in schedule-heightened aggression by intra-raphé infusion of a different 5- $\mathrm{HT}_{1 \mathrm{~B}}$ agonist, CP-93,129. Both CP-94,253 and CP-93,129 have a high affinity for the $5-\mathrm{HT}_{1 \mathrm{~B}}$ receptor but differ in their relative affinities for the $5-\mathrm{HT}_{1 \mathrm{~B}}$ receptor $v s$ the $5-\mathrm{HT}_{1 \mathrm{~A}}$ receptor $\left(\mathrm{K}_{\mathrm{i}}\right.$ for $5-\mathrm{HT}_{1 \mathrm{~A}}: 5-\mathrm{HT}_{1 \mathrm{~B}}=44.5$ and $27.27 \mathrm{nM}$, respectively; Koe et al, 1992a, b; Perez et al, 1998; Pineyro and Blier, 1999). The greater relative affinity of CP-93,129 for the $5-\mathrm{HT}_{1 \mathrm{~A}}$ receptor may account for why this ligand was able to effectively reduce heightened aggressive behavior in contrast to CP-94,253 when infused into a region abundant with $5-\mathrm{HT}_{1 \mathrm{~A}}$ receptors. Nonetheless, the resistance of Alc-heightened aggression to modulation by both $(+) 8-\mathrm{OH}-\mathrm{DPAT}$ and CP-94,253 does indicate that this form of escalated aggression is not under direct modulation by the DRN and that the acute, pro-aggressive effect of $1.0 \mathrm{~g} / \mathrm{kg}$ Alc is sufficient to counteract the antiaggressive effects of these ligands (Miczek et al, 1998; Fish et al, 1999).

Both impulsive behavior and aggression have been linked to dysfunctions of the prefrontal cortex (Blair, 2004). In humans, atrophy of the frontal cortex is positively correlated with increases in violent behavior, and aggressive and violent individuals have reduced regional cerebral blood flow and function, primarily in the orbital prefrontal cortex (Bach et al, 1971; Duffy and Campbell, 1994; Raine et al, 1994, 1998; Soderstrom et al, 2000; Soloff et al, 2003). In highly aggressive rats, c-Fos immunoreactivity, a marker of neuronal activity, was significantly elevated in the medial prefrontal and orbitofrontal regions of the prefrontal cortex, again, highlighting the importance of this region in the 
regulation of aggression (Halász et al, 2006; Haller et al, 2006). Our studies have added to this evidence by showing a pharmacological enhancement of Alc-heightened aggression when CP-94,253 is infused into the mPFC and no effect when infused into either the OFC or the lateral septum, regions immediately anterior and posterior to the $\mathrm{MPFC}$, respectively. This study, along with others, has confirmed that $5-\mathrm{HT}_{1 \mathrm{~B}}$ activation in the prefrontal cortex leads to either increases or decreases in aggressive behavior depending on both the animal model and subregion of the cortex that is targeted (de Almeida et al, 2006). Interestingly, these findings are in accordance with the demonstration that $5-\mathrm{HT}_{1 \mathrm{~B}}$ mRNA in the prefrontal cortex is significantly reduced in mice that have been characterized as Alc-heightened aggressors (Chiavegatto et al, 2007). A reduction in expression of the $5-\mathrm{HT}_{1 \mathrm{~B}}$ receptor, in the targeted region of the microinjection, is a plausible explanation for why Alc-naïve (de Almeida et al, 2006) and Alc-heightened aggressive mice (experiment 2) exhibit such profoundly different behavioral responses to intracortical CP-94,253 microinjections.

Initially, the aggression-heightening effect of the $5-\mathrm{HT}_{1 \mathrm{~B}}$ agonist, CP-94,253, was surprising because it does not reflect the prevailing findings proposing an anti-aggressive role for this receptor (De Almeida et al, 2001, 2006; Fish et al, 1999; Grimes and Melloni, 2005; Olivier and Van Oorschot, 2005; Bannai et al, 2007; Veiga et al, 2007). However, in addition to reductions in $5-\mathrm{HT}_{1 \mathrm{~B}} \mathrm{mRNA}$, Chiavegatto et al (2007) also found decreases in prefrontal mRNA transcript for $5-\mathrm{HT}_{1 \mathrm{~A}}, 5-\mathrm{HT}_{2 \mathrm{~A}}, 5-\mathrm{HT}_{2 \mathrm{C}}, 5-\mathrm{HT}_{6}$, and $5-\mathrm{HT}_{7}$ receptors. Since CP-94,253 potentiated Alc-heightened aggression only at the highest dose tested $(1 \mu \mathrm{g})$, we speculate that the selectivity for $5-\mathrm{HT}_{1 \mathrm{~B}}$ receptors might be diminished, particularly in light of reduced expression; activity at lower-affinity receptors may contribute to this effect (Koe et al, 1992b). The affinity of CP-94,253 at 5- $\mathrm{HT}_{6}$ and $5-\mathrm{HT}_{7}$ receptors is not known and its relative affinity for the $5-\mathrm{HT}_{1 \mathrm{D}}$ receptor is presumably heightened, given the reduced expression of the $5-\mathrm{HT}_{1 \mathrm{~A}}$ and $5-\mathrm{HT}_{1 \mathrm{~B}}$ receptors pointing to these receptors as possible mechanisms of action for the aggression-heightening effects of this ligand.

Species-typical aggression was not attenuated after CP-94,253 injection into the MPFC and LS; this result is in accordance with the findings of de Almeida et al (2006), who injected this $5-\mathrm{HT}_{1 \mathrm{~B}}$ agonist into the $\mathrm{mPFC}$ of Alc-naïve mice prior to an aggressive encounter. However, they found a significant reduction in aggressive behavior when CP-94,253 was infused into the OFC at the same dose that produced no effect in experiment 3. Differential results between these studies are most likely the result of variations in experimental history of the subjects (naïve $v s$ chronic Alc drinkers) coupled with differences in the constitutive levels of $5-\mathrm{HT}_{1 \mathrm{~B}}$ receptors in these regions (Chiavegatto et al, 2007). Together, these studies suggest that the divergent effect of CP-94,253 in the mPFC $v s$ the OFC indicates that the mPFC is functionally distinct in its modulation of aggressive behavior.

The microdialysis findings further support the hypothesis that there is a significant interaction between medial prefrontal activity of $\mathrm{CP}-94,253$ and Alc drinking. In naïve mice, local application of CP-94,253 significantly increases extracellular levels of $5-\mathrm{HT}$; this effect was not only antagonized but was reversed in mice with a history of Alc drinking. These results generate several interesting hypotheses. First, it has been demonstrated repeatedly that systemic injection of CP-94,253 decreases extracellular levels of 5-HT in the prefrontal cortex, striatum, and hippocampus (Knobelman et al, 2000; Johnson et al, 2001; De Groote et al, 2003; Miczek et al, 2004a). Because this attenuation was not observed in the mPFC during local perfusion of the same ligand, it is likely that the decreased 5-HT seen in these terminal regions after systemic administration is due to a reduction in 5-HT cell firing and release following somatodendritic receptor stimulation rather than to activity at pre- or post-synaptic terminal receptors. Second, the profound difference in the effect of CP-94,253 on prefrontal 5-HT levels in a naïve $v s$ chronic Alc-drinking mouse suggests that even moderate Alc drinking is altering the serotonergic 'tone' of the Alc drinker, which may be reflected, in the present experiment, as a different neurochemical response to a pharmacological challenge. Chronic Alc self-administration leads to longlasting neuroadaptive changes in multiple neurotransmitter systems and in vivo, ethanol reduces the persistent activity of prefrontal cortical neurons (McBride and Li, 1998; Tu et al, 2007). Some studies have suggested that the $5-\mathrm{HT}_{1 \mathrm{~B}}$ receptor is involved in regulating Alc self-administration and preference (Crabbe et al, 1996; Hoplight et al, 2006). The currently studied mice self-administered moderate doses of Alc for a minimum of 2 months prior to the microinjection experiments. Differences in basal levels of a neurotransmitter are ideally quantified using a no-net-flux method that calculates a standard curve for the amount of neurotransmitter in a given region by perfusing several known concentration through the microdialysis probe and the amount retained in the dialysate (Parsons and Justice, 1994). The use of this method in this experiment was not feasible due to limitations in sample collection and the high degree of difficulty in analyzing small samples from a mouse mPFC but it is acknowledged that these are important future experiments.

At high concentrations, CP-94,253 may be recruiting post-synaptic receptors, which would account for the opposite behavioral response seen in the DRN vs mPFC. Inactivation of somatodendritic $5-\mathrm{HT}_{1 \mathrm{~B}}$ receptors by intraraphé 5,7-DHT or PCPA injections fails to attenuate the antiaggressive- and antidepressant-like effects of 5- $\mathrm{HT}_{1 \mathrm{~B}}$ agonists, suggesting that these behaviors are modulated by post-synaptic $5-\mathrm{HT}_{1 \mathrm{~B}}$ heteroreceptor activity (Clark and Neumaier, 2001; de Almeida et al, 2001; Tatarczyñska et al, 2005). Local administration of $5-\mathrm{HT}_{1 \mathrm{~B}}$ agonists decreases extracellular levels of glutamate in the prefrontal cortex, which, presumably, is due to activation of $5-\mathrm{HT}_{1 \mathrm{~B}}$ receptors located on cortical glutamatergic neurons (Gołembiowska and Dziubina, 2002). Mounting evidence implicates a role for mPFC glutamate in the modulation of impulsive behavior and cognitive impairments (Goff and Coyle, 2001). Specifically, pharmacological antagonism of NMDA receptors in the prefrontal cortex or prefrontal legions have been shown to increase perseverative and anticipatory responding in rodent models of impulsive choice (Murphy et al, 2005; Carli et al, 2006; Baviera et al, 2007). Alc, being a glutamatergic antagonist, might act in a similar way to produce prefrontal behavioral impairments and to interact 
with the decrease in cortical excitatory neurotransmission induced by CP-94,253, which could functionally result in increased impulsivity and aggression (Lovinger et al, 1989).

In conclusion, one of the most consistent findings in aggression research is that 5-HT agonists decrease aggressive behavior in multiple species, under various conditions involving receptors in the $5-\mathrm{HT}_{1}$ and $5-\mathrm{HT}_{2}$ families (Olivier and Mos, 1986; Sanchez et al, 1993; Muehlenkamp et al, 1995; Miczek et al, 1998, 2007; Fish et al, 1999; de Almeida et al, 2001). The heightened aggressive behavior that we have shown after medial prefrontal microinjection of $\mathrm{CP}$ 94,253 is intriguing because it (1) further confirms that the $5-\mathrm{HT}_{1 \mathrm{~B}}$ receptor is one of the few receptors that specifically modulates aggressive behavior and (2) reveals that selective increases in aggressive behavior are possible via a serotonergic mechanism. Further study of these neurochemical mechanisms that regulate Alc-heightened aggression is important because they facilitate understanding of one facet of Alc abuse-behavioral disruptions and impaired impulse control.

\section{ACKNOWLEDGEMENTS}

We would like to thank J Thomas Sopko for his outstanding technical assistance, Rachel vanTrigt and Jeremy Maggin for their assistance in conducting the self-administration and aggression experiments, Satoko Bannai for her tremendous help with the HPLC, and Dr Eric W Fish for consultation and advice.

\section{DISCLOSURE/CONFLICT OF INTEREST}

The authors declare that this research was supported by an NIAAA grant to KAM (AA013983) and by Ajinomoto Co. Inc. (MB). The authors declare that except for income received by their primary employers, they have not received any financial support or compensation that could be perceived as a conflict of interest.

\section{REFERENCES}

Adell A, Carceller A, Artigas F (1993). In vivo brain dialysis study of the somatodendritic release of serotonin in the raphe nuclei of the rat: Effects of 8-Hydroxy-2-(Di- $\{\mathrm{In}\}$ - Propylamino)tetralin. J Neurochem 60: 1673-1681.

Adell A, Celada P, Artigas F (2001). The role of 5- $\mathrm{HT}_{1 \mathrm{~B}}$ receptors in the regulation of serotonin cell firing and release in the rat brain. J Neurochem 79: 172-182.

Bach YR, Lion JR, Climent CE, Ervin FR (1971). Episodic dyscontrol: A study of 130 violent patients. Am J Psychiatry 127: 1473-1478.

Bannai M, Fish EW, Faccidomo S, Miczek KA (2007). Antiaggressive effects of agonists at $5-\mathrm{HT}_{1 \mathrm{~B}}$ receptors in the dorsal raphe nucleus of mice. Psychopharmacology (Berl) 193: 295-304.

Baviera M, Invernizzi RW, Carli M (2007). Haloperidol and clozapine have dissociable effects in a model of attentional performance deficits induced by blockade of NMDA receptors in the mPFC. Psychopharmacology (Berl) 196: 269-280.

Bechara A, Tranel D, Damasio H (2000). Characterization of the decision-making deficit of patients with ventromedial prefrontal cortex lesions. Brain 123(Part 11): 2189-2202.
Best M, Williams JM, Coccaro EF (2002). Evidence for a dysfunctional prefrontal circuit in patients with an impulsive aggressive disorder. Proc Natl Acad Sci USA 99: 8448-8453.

Blair RJR (2004). The roles of orbital frontal cortex in the modulation of antisocial behavior. Brain Cogn 55: 198-208.

Brower MC, Price BH (2001). Neuropsychiatry of frontal lobe dysfunction in violent and criminal behaviour: a critical review. J Neurol Neurosurg Psychiatry 71: 720-726.

Bruinvels AT, Landwehrmeyer B, Gustafson EL, Durkin MM, Mengod G, Branchek TA et al (1994). Localization of 5- $\mathrm{HT}_{1 \mathrm{~B}}$, $5-\mathrm{HT}_{1 \mathrm{D} \alpha}, 5-\mathrm{HT}_{1 \mathrm{E}}$ and $5-\mathrm{HT}_{1 \mathrm{~F}}$ receptor messenger RNA in rodent and primate brain. Neuropharmacology 33: 367-386.

Bruinvels AT, Palacios JM, Hoyer D (1993). Autoradiographic characterisation and localisation of $5-\mathrm{HT}_{1 \mathrm{D}}$ compared to $5-\mathrm{HT}_{1 \mathrm{~B}}$ binding sites in rat brain. Naunyn Schmiedebergs Arch Pharmacol 347: 569-582.

Carli M, Baviera M, Invernizzi RW, Balducci C (2006). Dissociable contribution of 5-HT1A and 5-HT2A receptors in the medial prefrontal cortex to different aspects of executive control such as impulsivity and compulsive perseveration in rats. Neuropsychopharmacology 31: 757-767.

Chance MRA, Mackintosh JH, Dixon AK (1973). The effects of ethyl alcohol on social encounters between mice. J Alcoholism 8: 90-93.

Chiavegatto S, Quadros IMH, Trindade A, Ambar G, Miczek KA (2007). Alcohol-heightened aggression in mice is associated with reduced mRNA levels of serotonin receptors in the prefrontal cortex. Alcohol Clin Exp Res 31: 190A.

Chudasama Y, Passetti F, Rhodes SEV, Lopian D, Desai A, Robbins TW (2003). Dissociable aspects of performance on the 5-choice serial reaction time task following lesions of the dorsal anterior cingulate, infralimbic and orbitofrontal cortex in the rat: differential effects on selectivity, impulsivity and compulsivity. Behav Brain Res 146: 105-119.

Clark MS, Neumaier JF (2001). The 5-HT1B receptor: behavioral implications. Psychopharmacol Bull 35: 170-185.

Coccaro EF (1992). Impulsive aggression and central serotonergic system function in humans: an example of a dimensional brainbehavior relationship. Int Clin Psychopharmacol 7: 3-12.

Crabbe JC, Phillips TJ, Feller DJ, Hen R, Wenger CD, Lessov CN et al (1996). Elevated alcohol consumption in null mutant mice lacking 5-HT1B serotonin receptors. Nat Genet 14: 98-101.

de Almeida RM, Rosa MM, Santos DM, Saft DM, Benini Q, Miczek KA (2006). 5- $\mathrm{HT}_{1 \mathrm{~B}}$ receptors, ventral orbitofrontal cortex, and aggressive behavior in mice. Psychopharmacology (Berl) 185: 441-450.

de Almeida RMM, Lucion AB (1997). 8-OH-DPAT in the median raphe, dorsal periaqueductal gray and corticomedial amygdala nucleus decreases, but the medial septal area it can increase maternal aggressive behavior in rats. Psychopharmacology (Berl) 134: 392-400.

de Almeida RMM, Nikulina EM, Faccidomo S, Fish EW, Miczek KA (2001). Zolmitriptan - a 5-HT1B/D agonist, alcohol, and aggression in mice. Psychopharmacology (Berl) 157: 131-141.

de Boer SF, Koolhaas JM (2005). 5- $\mathrm{HT}_{1 \mathrm{~A}}$ and 5- $\mathrm{HT}_{1 \mathrm{~B}}$ receptor agonists and aggression: A pharmacological challenge of the serotonin deficiency hypothesis. Eur J Pharmacol 526: 125-139.

De Groote L, Olivier B, Westenberg HG (2003). Role of 5-HT 1 B receptors in the regulation of extracellular serotonin and dopamine in the dorsal striatum of mice. Eur J Pharmacol 476: 71-77.

Duffy JD, Campbell JJ (1994). The regional prefrontal syndromesa theoretical and clinical overview. J Neuropsychiatry Clin Neurosci 6: 379-387.

Ferrari PF, van Erp AMM, Tornatzky W, Miczek KA (2003). Accumbal dopamine and serotonin in anticipation of the next aggressive episode in rats. Eur J Neurosci 17: 371-378. 
Fish EW, Faccidomo S, Miczek KA (1999). Aggression heightened by alcohol or social instigation in mice: reduction by the $5-\mathrm{HT}_{1 \mathrm{~B}}$ receptor agonist CP-94,253. Psychopharmacology (Berl) 146: 391-399.

Fish EW, McKenzie-Quirk SD, Bannai M, Miczek KA (2007). $5-\mathrm{HT}_{1 \mathrm{~B}}$ receptor inhibition of alcohol-heightened aggression in mice: comparison to drinking and running. Psychopharmacology (Berl) (E-pub 2007 Dec 11).

Garattini S, Giacalone E, Valzelli L (1967). Isolation, aggressiveness and brain 5-hydroxytryptamine turnover. J Pharm Pharmacol 19: $338-339$.

Giacalone E, Tansella M, Valzelli L, Garattini S (1968). Brain serotonin metabolism in isolated aggressive mice. Biochem Pharmacol 17: 1315-1327.

Goff DC, Coyle JT (2001). The emerging role of glutamate in the pathophysiology and treatment of schizophrenia. Am J Psychiatry 158: 1367-1377.

Gołembiowska K, Dziubina A (2002). Inhibition of amino acid release by 5 -HT1B receptor agonist in the rat prefrontal cortex. Pol J Pharmacol 54: 625-631.

Grafman J, Schwab K, Warden D, Pridgen A, Brown HR, Salazar AM (1996). Frontal lobe injuries, violence, and aggression: A report of the Vietnam Head Injury Study. Neurology 46: 1231-1238.

Grant EC, Mackintosh JH (1963). A comparison of the social postures of some common laboratory rodents. Behaviour 21: 246-295.

Grimes JM, Melloni Jr RH. (2005). Serotonin-1B receptor activity and expression modulate the aggression-stimulating effects of adolescent anabolic steroid exposure in hamsters. Behav Neurosci 119: 1184-1194.

Halász J, Tóth M, Kalló I, Liposits Z, Haller J (2006). The activation of prefrontal cortical neurons in aggression-a double labeling study. Behav Brain Res 175: 166-175.

Haller J, Tóth M, Halász J, DeBoer SF (2006). Patterns of violent aggression-induced brain c-fos expression in male mice selected for aggressiveness. Physiol Behav 88: 173-182.

Higley JD, Mehlman PT, Higley SB, Fernald B, Vickers J, Lindell SG et al (1996). Excessive mortality in young free-ranging male nonhuman primates with low cerebrospinal fluid 5-hydroxyindoleacetic acid concentrations. Arch Gen Psychiatry 53: 537-543.

Hoplight BJ, Sandygren NA, Neumaier JF (2006). Increased expression of 5-HT1B receptors in rat nucleus accumbens via virally mediated gene transfer increases voluntary alcohol consumption. Alcohol 38: 73-79.

Hoyer D, Engel G, Kalkman HO (1985). Characterization of the $5-\mathrm{HT}_{1 \mathrm{~B}}$ recognition site in rat brain: Binding studies with $(-)^{[125 I]}$ iodocyanopindolol. Eur J Pharmacol 118: 1-12.

Johnson DE, Rollema H, Schmidt AW, McHarg AD (2001). Serotonergic effects and extracellular brain levels of eletriptan, zolmitriptan and sumatriptan in rat brain. Eur J Pharmacol 425: 203-210.

Knobelman DA, Kung HF, Lucki I (2000). Regulation of extracellular concentrations of 5-hydroxytryptamine (5-HT) in mouse striatum by $5-\mathrm{HT}_{1 \mathrm{~A}}$ and $5-\mathrm{HT}_{1 \mathrm{~B}}$ receptors. $J$ Pharmacol Exp Ther 292: 1111-1117.

Koe BK, Lebel LA, Fox CB, Macor JE (1992a). Binding and uptake studies with $[\mathrm{H}-3]$ CP-93,129, a radiolabeled selective $5-\mathrm{HT}_{1 \mathrm{~B}}$ receptor ligand. Drug Dev Res 25: 67-74.

Koe BK, Nielsen JA, Macor JE, Heym J (1992b). Biochemical and behavioral studies of the $5-\mathrm{HT}_{1 \mathrm{~B}}$ receptor agonist, CP-94,253. Drug Dev Res 26: 241-250.

Lister RG, Hilakivi LA (1988). The effects of novelty, isolation, light and ethanol on the social behavior of mice. Psychopharmacology (Berl) 96: 181-187.

Lovinger DM, White G, Weight FF (1989). Ethanol inhibits NMDAactivated ion current in hippocampal neurons. Science 243: 1721-1724.
McBride WJ, Li TK (1998). Animal models of alcoholism: neurobiology of high alcohol-drinking behavior in rodents. Crit Rev Neurobiol 12: 339-369.

Mehlman Pt, Higley JD, Faucher I, Lilly AA, Taub DM, Vickers J et al (1994). Low CSF 5-HIAA concentrations and severe aggression and impaired impulse control in nonhuman primates. Am J Psychiatry 151: 1485-1491.

Miczek KA, de Almeida RMM (2001). Oral drug self-administration in the home cage of mice: alcohol-heightened aggression and inhibition by the 5-HT1B agonist anpirtoline. Psychopharmacology (Berl) 157: 421-429.

Miczek KA, Faccidomo S, de Almeida RMM, Bannai M, Fish EW, DeBold JF (2004a). Escalated aggressive behavior: pharmacotherapeutic approaches and opportunities. Ann NY Acad Sci 1036: 336-355.

Miczek KA, Faccidomo SP, Fish EW, DeBold JF (2007). Neurochemistry and molecular neurobiology of aggressive behavior. In: JD Blaustein (ed). Behavioral Neurochemistry, Neuroendocrinology and Molecular Neurobiology. Handbook of Neurochemistry and Molecular Neurobiology. Springer: New York, pp 286-316.

Miczek KA, Fish EW (2006). Monoamines, GABA, Glutamate, and Aggression. In: Nelson RJ (ed). Biology of Aggression. Oxford University Press: New York, pp 114-149.

Miczek KA, Fish EW, de Almeida RMM, Faccidomo S, DeBold JF (2004b). Role of alcohol consumption in escalations to violence. Ann NY Acad Sci 1036: 278-289.

Miczek KA, Hussain S, Faccidomo S (1998). Alcohol-heightened aggression in mice: attenuation by $5-\mathrm{HT}_{1 \mathrm{~A}}$ receptor agonists. Psychopharmacology (Berl) 139: 160-168.

Miczek KA, O'Donnell JM (1978). Intruder-evoked aggression in isolated and nonisolated mice: effects of psychomotor stimulants and L-dopa. Psychopharmacology 57: 47-55.

Miczek KA, O’Donnell JM (1980). Alcohol and chlordiazepoxide increase suppressed aggression in mice. Psychopharmacology (Berl) 69: 39-44.

Miczek KA, Weerts EM, DeBold JF (1993). Alcohol, benzodiazepine-GABA $A_{A}$ receptor complex and aggression: ethological analysis of individual differences in rodents and primates. J Stud Alcohol suppl 11: 170-179.

Mos J, Olivier B, Poth M, Van Oorschot R, Van Aken H (1993). The effects of dorsal raphe administration of eltoprazine, TFMPP and 8-OH- DPAT on resident intruder aggression in the rat. Eur J Pharmacol 238: 411-415.

Muehlenkamp F, Lucion A, Vogel WH (1995). Effects of selective serotenergic agonists on aggressive behavior in rats. Pharmacol Biochem Behav 50: 671-674.

Murphy ER, Dalley JW, Robbins TR (2005). Local glutamate receptor antagonism in the rat prefrontal cortex disrupts response inhibition in a visuospatial attentional task. Psychopharmacology (Berl) 179: 99-107.

National Research Council (1996). Guide for the Care and Use of Laboratory Animals. National Academy Press: Washington DC.

Olivier B, Mos J (1986). Serenics and aggression. Stress Med 2: 197-209.

Olivier B, Mos J (1992). Rodent models of aggressive behavior and serotonergic drugs. Prog Neuropsychopharmacol Biol Psychiatry 16: $847-870$.

Olivier B, Mos J, Van der Heyden J, Hartog J (1989). Serotonergic modulation of social interactions in isolated male mice. Psychopharmacology (Berl) 97: 154-156.

Olivier B, Mos J, Van Oorschot R, Hen R (1995). Serotonin receptors and animal models of aggressive behavior. Pharmacopsychiatry 28: 80-90.

Olivier B, Van Oorschot R (2005). 5-HT1B receptors and aggression: A review. Eur J Pharmacol 526: 207-217.

Parsons LH, Justice Jr JB. (1994). Quantitative approaches to in vivo brain microdialysis. Crit Rev Neurobiol 8: 189-220. 
Paxinos G, Franklin KBJ (2001). The Mouse Brain in Stereotaxic Coordinates Second Edition Academic Press: San Diego.

Peeke HVS, Ellman GE, Herz MJ (1973). Dose dependent alcohol effects on the aggressive behavior of the conflict cichlid (Cichlasoma nigrofaciatum). Behav Biol 8: 115-122.

Perez M, Pauwels PJ, Fourrier C, Chopin P, Valentin JP, John GW et al (1998). Dimerization of sumatriptan as an efficient way to design a potent, centrally and orally active 5-HT1B agonist. Bioorg Med Chem Lett 8: 675-680.

Pineyro G, Blier P (1999). Autoregulation of serotonin neurons: role in antidepressant drug action. Pharmacol Rev 51: 533-591.

Raine A, Buchsbaum MS, Stanley J, Lottenberg S, Abel L, Stoddard J (1994). Selective reductions in prefrontal glucose metabolism in murderers. Biol Psychiatry 36: 365-373.

Raine A, Meloy JR, Bihrle S, Stoddard J, LaCasse L, Buchsbaum MS (1998). Reduced prefrontal and increased subcortical brain functioning assessed using positron emission tomography in predatory and affective murderers. Behav Sci Law 16: 319-332.

Sanchez C, Arnt J, Hyttel J, Moltzen EK (1993). The role of serotonergic mechanisms in inhibition of isolation-induced aggression in male mice. Psychopharmacology (Berl) 110: 53-59.

Sari Y (2004). Serotonin1B receptors: from protein to physiological function and behavior. Neurosci Biobehav Rev 28: 565-582.

Sari Y, Miquel MC, Brisorgueil MJ, Ruiz G, Doucet E, Hamon M et al (1999). Cellular and subcellular localization of 5-Hydro-

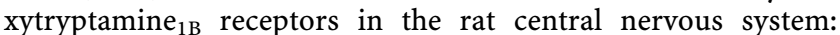
immunocytochemical, autoradiographic and lesion studies. Neuroscience 88: 899-915.
Soderstrom H, Tullberg M, Wikkelso C, Ekholm S, Forsman A (2000). Reduced regional cerebral blood flow in non-psychotic violent offenders. Psychiatry Res 98: 29-41.

Soloff PH, Meltzer CC, Becker C, Greer PJ, Kelly TM, Constantine D (2003). Impulsivity and prefrontal hypometabolism in borderline personality disorder. Psychiatry Res 123: 153-163.

Spinella M (2004). Neurobehavioral correlates of impulsivity: evidence of prefrontal involvement. Int J Neurosci 114: 95-104.

Tatarczyñska E, Antkiewicz-Michaluk L, Kłodziñska A, Stachowicz K, Chojnacka-Wójcik E (2005). Antidepressant-like effect of the selective 5-HT1B receptor agonist CP 94253: a possible mechanism of action. Eur J Pharmacol 516: 46-50.

Tu Y, Kroener S, Abernathy K, Lapish C, Seamans J, Chandler LJ et al (2007). Ethanol inhibits persistent activity in prefrontal cortical neurons. J Neurosci 27: 4765-4775.

Van Der Vegt BJ, de Boer SF, Buwalda B, de Ruiter AJ, de Jong JG, Koolhaas JM (2001). Enhanced sensitivity of postsynaptic serotonin-1A receptors in rats and mice with high trait aggression. Physiol Behav 74: 205-211.

van Erp AMM, Miczek KA (2000). Aggressive behavior, increased accumbal dopamine, and decreased cortical serotonin in rats. J Neurosci 20: 9320-9325.

Veiga CP, Miczek KA, Lucion AB, Almeida RM (2007). Effect of 5-HT1B receptor agonists injected into the prefrontal cortex on maternal aggression in rats. Braz J Med Biol Res 40: $825-830$.

Virkkunen M, Linnoila M (1993). Brain serotonin, Type II alcoholism and impulsive violence. J Stud Alcohol 11: 163-169.

Supplementary Information accompanies the paper on the Neuropsychopharmacology website (http://www.nature.com/npp) 